\title{
SPODNOBADENSKÉ SEDIMENTY KARPATSKÉ PŘEDHLUBNĚ NA LOKALITĚ PTENÍ
}

\author{
Lower Badenian deposits of the Carpathian Foredeep on the locality Ptení \\ Slavomír Nehyba' $\leftrightarrows$, Marie Dvořáková', Naděžda Hrozová', Vladimíra Jašková \\ 'Ústav geologických věd PřF MU, Kotlářská 2, 61137 Brno \\ ${ }^{2}$ Muzeum Prostějovska, náměstí T. G. Masaryka 2, 79601 Prostějov
}

Key words: facies analysis, gamma-ray spectrometry, depositional environment, transgressive-regressive cycles, distal palaeovalley

\begin{abstract}
Neogene deposits of the Carpathian Foredeep were studied newly in the sedimentary succession from the drill hole Pteni 1. Three identified facies associations represent deposits of fluvio-deltaic, nearshore and open marine environments. The facies associations are organized into two upward deepening and upward fining cycles which are interpreted as transgressive-regressive cycles. Source area was located in the adjacent geological units with strong dominance of Culmian rocks. The source area was relative stable, material was buried relative rapidly with low role of its reworking. The studied deposits are connected with filling of a distal palaeovalley formed on the foreland plate and oriented oblique to the main basin axis.
\end{abstract}

Úvod

Reliktní výskyty sedimentů karpatské předhlubně ležící na východním okraji Českého masivu poskytují důležitá data o vývoji této sedimentární pánve. Především spodnobadenské sedimenty na střední Moravě byly v poslední době nově revidovány řadou vrtů (Nehyba, Jašková 2012; Zágoršek et al. 2012; Zborník et al. 2013; Tomanová Petrová 2016 atd.). K těmto lokalitám se řadí také výskyt v okolí obce Ptení. Obec Ptení leží přibližně $16 \mathrm{~km}$ sz. od Prostějova a zhruba $35 \mathrm{~km}$ jz. od města Olomouc. Na území obce byl proveden vrt Ptení 1 (GPS lokalizace

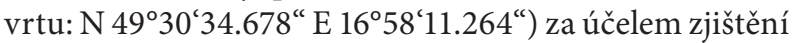
bližších dat o sedimentárním profilu spodnobadenských sedimentů, které zde nejsou odkryty přirozeným způsobem. Pozice vrtu je prezentována na obrázku 1.

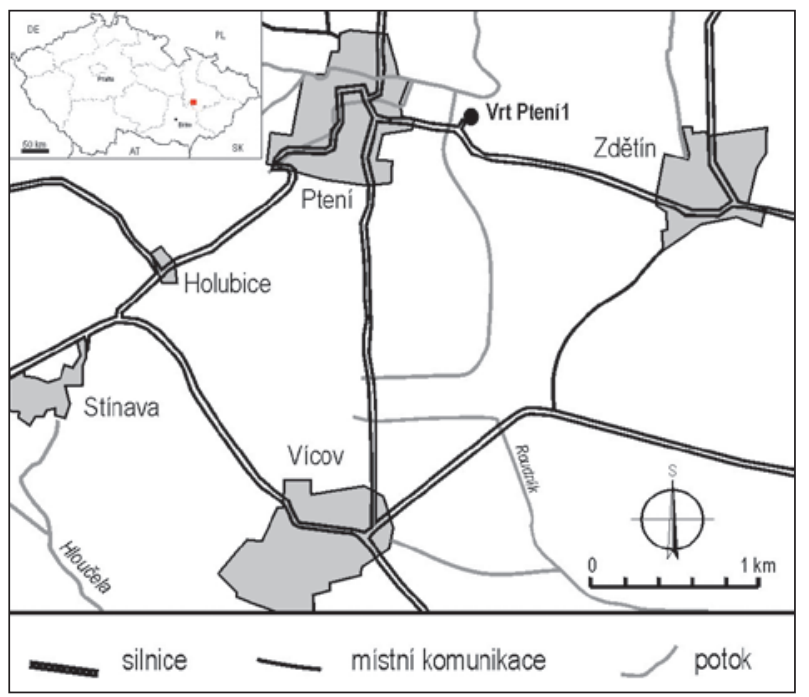

Obr. 1: Pozice vrtu Ptení 1.

Fig. 1: Position of drill hole Ptení 1.

$\square$ slavek@sci.muni.cz

DOI: https://doi.org/10.5817/GVMS2018-1-2-28
Předneogenní podloží této lokality je tvořeno spodnokarbonskými kulmskými sedimenty myslejovického souvrství (Mísař et al. 1983). Studované sedimenty na lokalitě geologicky náleží do karpatské předhlubně Západních Karpat, konkrétně k její stř̌ední části. Spitzner $(1898,1904)$ popsal z povrchových sběrů u ptenského hřbitova drobivý jíl s úlomky lastur, ostny ježovek a foraminifery. O výskytu neogenního jílu zde se zmiňuje i Jedlitschka (1937). Remeš (1933) nechal u ptenského hřbitova vykopat průzkumnou sondu. Kalabis (1935) popisuje na lokalitě u ptenského hřbitova řasové vápence a vápnité jíly („tégly“) spodního badenu s hojnými mechovkami, foraminiferami a mlži. Kalabis (1939) popisuje mezi Ptením a Holubicemi podobný výskyt řasových vápenců. Novák (1975) revidoval spodnobadenské sedimenty v okolí Ptení a předpokládá jejich velmi malou mocnost. Rozsah miocenních sedimentů v okolí Ptení hodnotil Synek (1998), který popisuje ústřice, červené řasy a mechovky.

\section{Metodika práce}

Plně jádrovaný vrt Ptení 1 byl hodnocen metodami sedimentární geologie. Vrt byl litologicky popsán a byla provedena faciální analýza podle zásad popsaných $\mathrm{v}$ publikacích Tuckera (1988), Walkera, Jamese (1992) a Nemece (2005). Bylo odebráno celkem 24 vzorků nezpevněných sedimentů $\mathrm{s}$ víceméně pravidelným krokem s ohledem na litologické složení vrtu. Na odebraných vzorcích byla provedena gamaspektrometrická analýza (vzorky o váze 184-360 g, doba měření 30 minut), granulometrická analýza, petrografická analýza psefitické frakce, posouzení tvaru a zaoblení klastů psefitické zrnitostní frakce (dle Powerse 1982) a orientační exoskopie vybraných zrn psamitické frakce. Gamaspektrometrická analýza byla realizována za účelem zjištění koncentrace radioaktivních izotopů draslíku, uranu a thoria na laboratorním gamaspektrometru GR - 320 SPEC. Celková radioaktivita byla vypočtena jako tzv. standardní gamazárení (SGR) dle vzorce SGR $[$ API $]=16,32 \times \mathrm{K}(\%)+8,09 \times \mathrm{U}(\mathrm{ppm})+3,93$ $\times$ Th $(\mathrm{ppm})-\mathrm{API} /$ American Petroleum Institute units. 
Zrnitostní analýza byla provedena kombinací metody sítování za mokra na normovaných sítech (Retsch AS - 200) a laserové difrakce (CILAS 1064). K určení zrnitostních charakteristik $(\mathrm{Mz}, \sigma \mathrm{I})$ byly využity vzorce podle Folka, Warda (1957). Hodnocení tvarové charakteristiky proběhlo pod binoklem (zrnitostní frakce nad $2 \mathrm{~mm}$ ) i elektronovým mikroskopem (zrnitostní frakce 0,5-1,0 mm).

\section{Výsledky}

Jádrovaný vrt dosáhl hloubky 13 m, kdy byl ukončen. Prakticky celá odvrtaná mocnost odpovídá neogenním (spodnobadenským) sedimentům (metráž cca 0,8-13,0 m), ćímž se nepotvrdily představy o malé mocnosti těchto sedimentů na zájmové lokalitě. Bylo vyčleněno 7 facií, které jsou podrobně popsány v tabulce č. 1 , spolu s jejich zrnitostní charakteristikou zjištěnou granulometrickým studiem a zjištěnými koncentracemi radioaktivních izotopů K, U, Th. Na obrázku č. 2 je znázorněn litologický profil vrtu doplněný o vybrané výsledky gamaspektrometrie a granulometrie.

Zrnitostní a petrografické charakteristiky byly rozhodující při identifikaci litofacií. Role primárních sedimentárních struktur byla menší vzhledem $\mathrm{k}$ jejich částečné destrukci, která byla způsobena technologií vrtání. Na základě prostorové distribuce a depozičních procesů byly litofacie seskupeny do faciálních asociací.
Byly vyčleněny celkem tři faciální asociace (FA). První faciální asociace je tvořena litofacií G. FA 1 vystupuje v nejspodnějších partiích vrtu v mocnosti přes tři metry a někde poblíž báze vrtu velmi pravděpodobně přímo nasedá na předneogenní podloží. FA 1 byla dále zjištěna v hloubce kolem $6 \mathrm{~m}$ (mocnost $75 \mathrm{~cm}$ ). Jedná se o špatně vytříděné relativně hrubozrnné sedimenty, které vykazují převážně masivní stavbu s náznaky planárního zvrstvení. Těleso FA 1 v hloubce 9,5-13,0 m vykazuje ostrou svrchní plochu spojenou s výrazným poklesem střední velikosti zrna i přítomností psefitických klastů a růstem vytřídění. Naopak svrchní plocha tělesa FA 1 v hloubce kolem $6 \mathrm{~m}$ je gradační, spojená mimo jiné i se zjemňováním (pokles střední velikosti zrna). Báze tělesa FA 1 je erozní, což odráží i přítomnost intraklastů podložních prachovitých písků. Přítomnost drti schránek měkkýšů je proměnlivá.

Sedimenty FA 1 jsou interpretovány jako terestrické sedimenty ovlivněné činností moře. Především těleso FA $1 \mathrm{v}$ hloubce kolem $6 \mathrm{~m}$ vykazuje charakteristiky tzv. transgresivního rezidua. Lze předpokládat fluviální, případně deltový (hrubozrnná delta) přínos materiálu, který byl částečně redistribuován činností moře. Vzhledem k chráněné pozici nebylo přepracování materiálu výrazné. Sedimenty FA 2 tvoří střední část vrtu a jsou tvořeny litofaciemi M2, M3, S1, S2, G a L. Převážná část asociace je však tvořena jemnozrnnými litofaciemi M2 (29,4\%)

Tab. 1: Stručný popis vyčleněných facií.

Tab. 1: List of lithofacies.

\begin{tabular}{|c|c|c|}
\hline Facie & Popis & Gamaspektrometrie \\
\hline M1 & $\begin{array}{l}\text { Světle šedozelený až místy hnědozelený jílovitý prach až prachovitý jíl, vápnitý, per- } \\
\text { letový lesk, dobře vytříděný, lokálně jemná planární laminace až místy čočkovité } \\
\text { zvrstvení, prítomnost celých schránek bivalvií. Ostrá báze, lokální rozdíly v zastou- } \\
\text { pení schránek i zachování laminace. Zastoupení jílové frakce se pohybovalo od } 23,6 \\
\text { do } 29,7 \% \text { (AVG } 27,5 \% \text { ), prachové frakce od } 70,4 \text { do } 76,4 \% \text { (AVG } 72,3 \% \text { ) a písčité } \\
\text { frakce do } 1,5 \% \text { (AVG } 0,2 \% \text { ). }\end{array}$ & $\begin{array}{l}\text { Hodnoty koncentrace K se pohybovaly v roz- } \\
\text { mezí od } 1,4 \text { do } 2,1 \% \text { (průměrná hodnota AVG } \\
1,8 \% \text { ), koncentrace U od } 2,2 \text { do } 3,4 \text { ppm (AVG } \\
2,6 \mathrm{ppm} \text { a hodnoty Th od } 5,4 \text { do } 7,6 \mathrm{ppm} \\
\text { (AVG } 7,0 \text { ppm). }\end{array}$ \\
\hline M2 & $\begin{array}{l}\text { Světle zelenošedý, šedý, místy rezavě hnědě smouhovaný jílovitý prach, písčito-jílovitý } \\
\text { prach, vápnitý, hojné schránky měkkýšŭ, planární laminace. Někdy hrubne směrem } \\
\text { vzhůru díky přibývání písčité a štěrkovité frakce. Zastoupení jílové frakce se pohybo- } \\
\text { valo od } 15,4 \text { do } 29,7 \% \text { (AVG } 24,8 \% \text { ), prachové frakce od } 33,6 \text { do } 70,4 \% \text { (AVG } 58,1 \% \text { ), } \\
\text { písčité frakce do } 21,8 \% \text { (AVG } 7,3 \% \text { ) a štěrkové frakce do } 29,2 \% \text { (AVG 9,7\%). }\end{array}$ & $\begin{array}{l}\text { Hodnoty koncentrace K se pohybovaly od } 2,6 \\
\text { do } 2,8 \%(\text { AVG } 2,7 \%) \text {, U od } 2,2 \text { do } 3,5 \mathrm{ppm} \\
\text { (AVG } 3,0 \mathrm{ppm}) \text { a Th od } 10,2 \text { do } 11,3 \mathrm{ppm} \\
\text { (AVG } 10,5 \mathrm{ppm})\end{array}$ \\
\hline M3 & $\begin{array}{l}\text { Světle šedý štěrkovito-jílovito-písčitý prach a štěrkovito-jílovito-prachovitý písek, špat- } \\
\text { ně vytříděný, vzácně klasty břidlic až } 3 \mathrm{~cm} \text { (osa A), vápnitý, drt’ schránek měkkýšu, ma- } \\
\text { sivní až lokálně laminovaný, ostrá báze. Zastoupení jílové frakce se pohybovalo od } 9,5 \\
\text { do } 22,4 \% \text { (AVG } 17,1 \% \text { ), prachové frakce od } 26,3 \text { do } 47,5 \% \text { (AVG } 37,4 \% \text { ), písčité } \\
\text { frakce od } 28,5 \text { do } 63,9 \% \text { (AVG } 44,3 \% \text { ) a štěrkové frakce } 0,3 \text { do } 1,7 \% \text { (AVG } 1,2 \% \text { ). }\end{array}$ & $\begin{array}{l}\text { Hodnoty koncentrace K se pohybovaly od } 2,0 \\
\text { do } 2,5 \% \text { (AVG 2,3 \%), U od 2,3 do 2,9 ppm } \\
\text { (AVG 2,7 ppm) a Th od } 7,3 \text { do } 9,8 \text { ppm (AVG } \\
8,3 \text { ppm). Průmérná hodnota koncentrace } \\
\text { K byla 2,3\%, U 2,7 ppm a hodnota Th byla } \\
8,3 \text { ppm. }\end{array}$ \\
\hline S1 & $\begin{array}{l}\text { Světle šedý až rezavě hnědý, zelenošedý velmi jemnozrnný písek až prachovitý písek, } \\
\text { dobře vytř́iděný, ostrý strop i báze, jemná planární laminace a čeřinové zvrstvení. }\end{array}$ & $\begin{array}{l}\text { Hodnota koncentrace } \mathrm{K} \text { je } 2,4 \% \text {, U 3,1 ppm } \\
\text { a Th } 7,5 \mathrm{ppm} \text {. }\end{array}$ \\
\hline S2 & $\begin{array}{l}\text { Světle hnědošedý, nazelenalý jílovito-prachovitý jemnozrnný až velmi jemnozrnný } \\
\text { vzácně až středozrnný písek s příměsí štěrku, vápnitý, planárně laminovaný, špatně } \\
\text { vytříděný, hojné schránky (měkky̌ši, mechovky?), směrem vzhůru přibývá schránek. } \\
\text { Zastoupení jílové frakce se pohybovalo od } 13,2 \text { do } 16,3 \% \text { (AVG } 14,75 \% \text { ), pracho- } \\
\text { vé frakce od } 33,5 \text { do } 37,6 \% \text { (AVG } 35,55 \% \text { ), písčité frakce od } 22,2 \text { do } 26,1 \% \text { (AVG } \\
24,15 \% \text { ) a štěrkové frakce od } 23,9 \text { do } 25,2 \% \text { (AVG } 24,1 \% \text { ). }\end{array}$ & $\begin{array}{l}\text { Hodnoty koncentrace K se pohybovaly v roz- } \\
\text { mezí od } 2,7 \text { do } 2,8 \% \text { (AVG 2,7 \%), U od } 3,0 \\
\text { do } 3,2 \mathrm{ppm} \text { (AVG } 3,1 \mathrm{ppm} \text { ) a Th od } 9,1 \\
\text { do } 9,8 \mathrm{ppm} \text { (AVG 9,4 ppm). }\end{array}$ \\
\hline L & $\begin{array}{l}\text { Lumachela - drt’ schránek měkkýšů a polozaoblených intraklastů šedého jílovce až jílo- } \\
\text { vitého prachovce, klasty mají velikost do } 1,5 \mathrm{~cm} \text {. Chaotická stavba. }\end{array}$ & \\
\hline G & $\begin{array}{l}\text { Světle šedý až rezavě hnědý, písčitý někdy až jílovito-písčitý štěrk s podpůrnou struk- } \\
\text { turou matrix, méně často podpůrná struktura valounů, vápnitý. Ostrá báze i strop, } \\
\text { směrem vzhưru zjemňování, někdy hrubé planární zvrstvení a protáhlé klasty rovno- } \\
\text { běžně s vrstevnatostí, jindy masivní. Klasty zaoblené, polozaoblené i poloostrohranné, } \\
\text { obvykle do } 2 \mathrm{~cm} \text { (osa A), vzácně až } 5 \mathrm{~cm} \text {, zjištěny intraklasty podložních prachovitých } \\
\text { písků. Lokálně drt' schránek měkkýšu. Zastoupení jílové frakce se pohybovalo od } 8,3 \\
\text { do } 14,7 \% \text { (AVG } 10,6 \% \text { ), prachové frakce od } 16,0 \text { do } 30,8 \% \text { (AVG } 24,8 \% \text { ), písčité frak- } \\
\text { ce od } 22,7 \text { do } 56,7 \% \text { (AVG } 35,7 \% \text { ) a štěrkové frakce od } 14,0 \text { do } 47,9 \% \text { (AVG } 28,2 \% \text { ). } \\
\text { Dle klasifikace Kukala (1985) se jedná o jílovito-písčito-prachovitý štěrk př́ípadně o jí- } \\
\text { lovito-prachovito-písčitý štěrk nebo o jílovito-štěrkovito-prachovitý písek. }\end{array}$ & $\begin{array}{l}\text { Hodnoty koncentrace K se pohybovaly od } 0,6 \\
\text { do } 2,6 \% \text { (AVG } 1,8 \%) \text {, U od 2,9 do 6,7 ppm } \\
\text { (AVG } 3,7 \mathrm{ppm} \text { ) a hodnoty Th od 5,2 do } 9,6 \mathrm{ppm} \\
\text { (AVG 7,6 ppm). }\end{array}$ \\
\hline
\end{tabular}




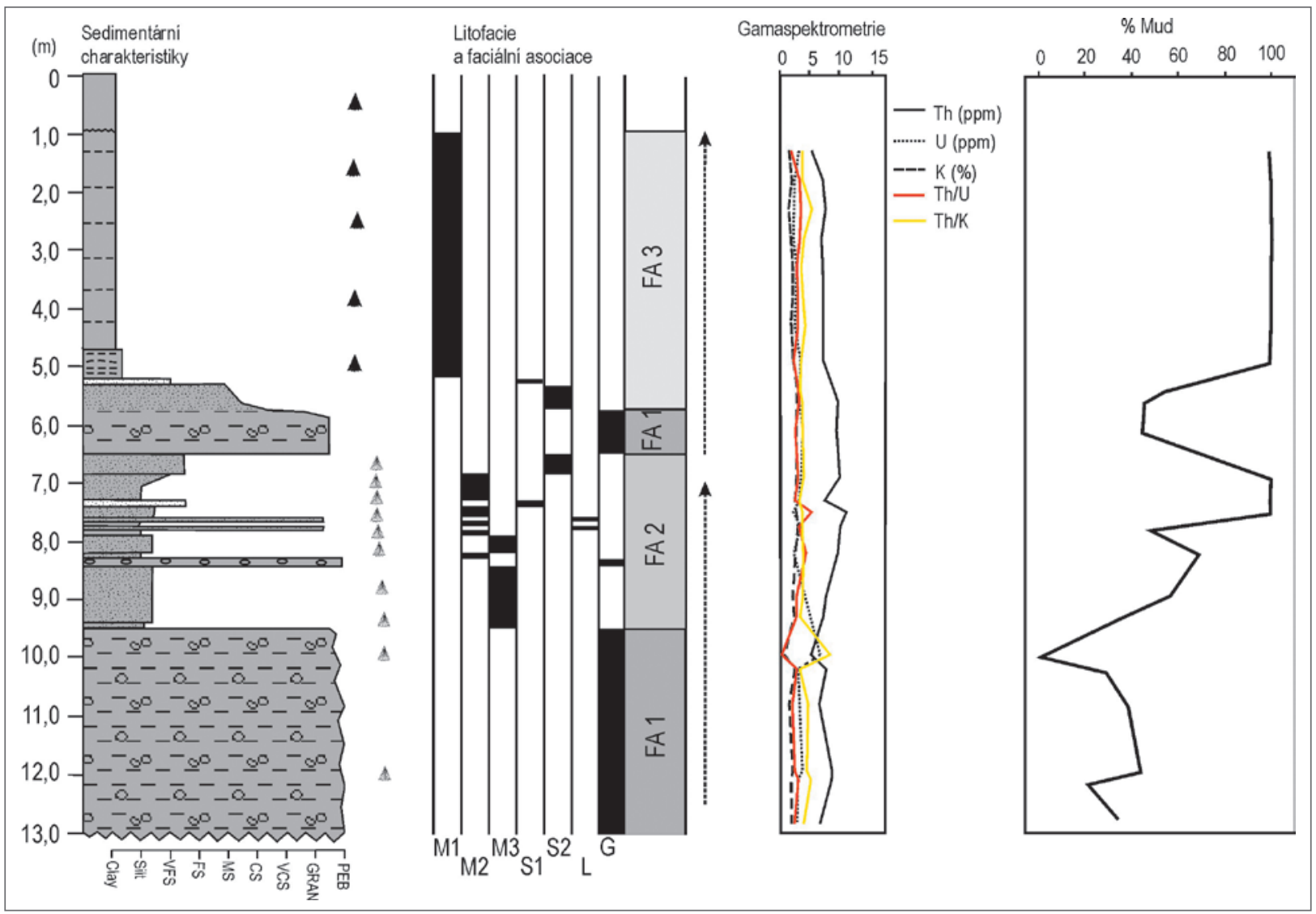

Obr. 2: Litologický profil vrtem Ptení $1 \mathrm{~s} \mathrm{hodnotami} \mathrm{gamaspektrometrie} \mathrm{a} \mathrm{zrnitostní} \mathrm{analýzy.}$

Fig. 2: Lithostratigraphic log of the drill hole Ptení 1 with results of gamma-ray spectrometry and grain-size analysis.

a především M3 (44,0 \%). Pro tuto faciální asociaci je zřetelná větší faciální pestrost a opakování střídání mocnějších poloh relativně jemnozrnných (facie M2, M3) s polohami s výraznějším zastoupením především písčité, př́ípadně štěrkovité frakce (litofacie S1, S2, G) nebo schránek měkkýšů (litofacie L). Nápadné je horší vytřrídění i jemnozrnných sedimentů a prrítomnost především planární laminace.

Sedimenty FA 2 jsou interpretovány jako sedimenty břežního pásma až spodního předbřeží (lower shoreface). Sedimentace byla výrazně ovlivněna periodickým přínosem hrubozrnného materiálu z blízkého kontinentu (katastrofické přívaly event. bouřková činnost).

Sedimenty FA 3 zachycují nejvyšší partie neogenního sledu zastiženého vrtem Ptení 1. Jsou tvořeny litofaciemi S1, S2 a M1, přičemž litofacie M1 výrazně převažuje $(86,8 \%)$. Písčité litofacie tvoří bazální části FA 3, výše převažuje monotónní těleso litofacie M1 mocné téměř $5 \mathrm{~m}$. Tyto sedimenty jsou nápadné jemnozrnností a dobrým vytř́íděním (zejména ve srovnání se zbytkem vrtu). Litofacie M1 odpovídá spodnobadenským pelitům tradičně označovaným jako "tégly“ a tyto partie neogenního profilu byly v minulosti nejspíše otevřeny kopanými sondami. V rámci vrtu nebyly zjištěny polohy odpovídající řasovým vápencům.

Sedimenty FA 3 jsou interpretovány jako sedimenty spodního předbřeží až otevřeného moře. Nápadná je výrazná redukce přínosu hrubšího klastického materiálu proti podložním FA.
Zjištěné hodnoty gamaspektrometrie ukazují, že hodnoty $\mathrm{K}$ a $\mathrm{U}$ jsou poměrně stabilní. Hodnoty zastoupení K se pohybují od 0,61 \% do 2,83\% (průměrná hodnota/AVG $=2,07 \%$, směrodatná odchylka/ $\mathrm{SO}=0,53 \%)$. Hodnoty koncentrací uranu se pohybují od 2,13 ppm do 6,65 ppm (AVG = 3,04 ppm, $\mathrm{SO}=0,88)$. Hodnoty zastoupení Th kolísají od 5,15 ppm po 11,24 ppm $(\mathrm{AVG}=8,0 \mathrm{ppm}, \mathrm{SO}=1,51)$. Celková radioaktivita SGR se pohybuje od 69,57 API po 113,09 API (AVG = 89,82 API, $\mathrm{SO}=13,27)$. Dle Hesseblo (1996) jsou koncentrace K převážně vysoké (52,2 \%) nebo střední (43,5\%), kdežto nízké jsou vzácné $(4,3 \%)$. Naopak koncentrace U jsou převážně nízké $(56,5 \%)$, př́padně střední $(39,1 \%)$ a vysoké jsou vzácné $(4,3 \%)$. Koncentrace Th jsou naprosto dominantně vysoké (91,7 \%), vzácně střední (8,3\%). Hodnoty celkové radioaktivity SGR lze považovat za střední (75\%), případně vysoké $(25 \%)$. Na celkové radioaktivitě se u hodnocených vzorků podílí zejména $\mathrm{K}(\mathrm{r}=0,81)$ a Th $(\mathrm{r}=0,84)$, kdežto role U je nízká $(\mathrm{r}=0,18)$. Hodnoty poměru Th/U se pohybují od 0,77 do 5,18 (AVG = 2,8, SO =0,81) a hodnoty poměru Th/K od 3,13 do 8,44 (AVG = 4,07, SO = 1,06). Průběhy koncentrací radioaktivních prvků i jejich poměru v rámci profilu vrtu jsou znázorněny na obrázku 2.

Koncentrace $\mathrm{K}$ a Th vykazují vysokou pozitivní korelaci $(\mathrm{r}=0,822)$, naopak nízkou zápornou korelaci vykazují koncentrace K a U $(r=-0,379)$ a U a Th $(r=-0,260)$. Koncentrace K vykazují slabou negativní až žádnou korelaci k zastoupení jílovité zrnitostní frakce $(r=-0,09)$, slabě 
negativní k zastoupení prachovité frakce $(\mathrm{r}=-0,16)$ a slabě pozitivní k zastoupení písčité frakce $(\mathrm{r}=0,12)$. Koncentrace U vykazují téměř shodnou hodnotu záporné korelace k zastoupení jílovité $(\mathrm{r}=-0,46)$ i prachovité frakce $(\mathrm{r}=-0,44)$. Mezi zastoupením písčité frakce a koncentracemi U byla zjištěna slabě pozitivní korelace $(r=0,29)$. Koncentrace thoria vykazují slabou negativní až žádnou korelaci k zastoupení jílovité zrnitostní frakce $(\mathrm{r}=-0,09)$, slabě negativní k zastoupení prachovité frakce $(\mathrm{r}=-0,19)$ a slabě pozitivní až žádnou korelaci k zastoupení písčité frakce $(r=0,04)$.

Pozitivní korelace Th a K ukazuje na společný zdroj signálu, kdežto negativní korelace těchto dvou prvků s U ukazuje, že původ signálu U je odlišný. Zdroj signálu $\mathrm{K}$ a Th bývá tradičně hledán $\mathrm{v}$ rámci jemné jílovité frakce. Nízké hodnoty korelace těchto prvků k jednotlivým zrnitostním frakcím ukazují na větší nestabilitu signálu a jejího zdroje.

Poměr Th/U je považován za indikátor geochemických facií/oxidačně-redukčních podmínek (Myers, Wignall 1987; Doveton 1991), nebo dokonce depozičního prostředí (Adams, Weaver 1958). Relativně vyšší hodnoty tohoto poměru (75\% nad hodnotu 2) ukazují na převažující sedimentaci v oxidačních podmínkách a mobilitu uranu. Převážné nízké hodnoty poměru Th/K (75\% pod 3) ukazují na nízké zastoupení kaolinitu ve studovaných vzorcích. Nízké hodnoty poměru Th/K jsou vcelku typické pro spodnobadenské sedimenty karpatské předhlubně (Nehyba, Jašková 2012; Zborník et al. 2013). Výrazné změny $\mathrm{v}$ hodnotě poměrů $\mathrm{Th} / \mathrm{U}$ i Th/K kolem metráže 9,5 m ukazují na výraznou změnu podmínek depozice.

Petrografické studium psefitické frakce prokázalo, že nejčastější jsou kulmské břidlice, jejichž podíl se stabilně pohybuje kolem $40 \%$. Dále relativně hojné byly klasty drob (kolem $30 \%)$. Proměnlivé je zastoupení starších slepenců (10-70\%). Méně časté byly klasty prachovců (kolem $2 \%$ ), křemenného pískovce a svorové ruly (do $1 \%$ ). Zastoupení křemene jeví výrazný nárůst ve spodních partiích vrtu. Zatímco ve vzorku z hloubky $10 \mathrm{~m}$ tvořily klasty křemene $1 \%$, ve vzorku z 12,95 m $27 \%$. Psefitické klasty jsou převážně poloostrohranné (66\%). Zastoupení polozaoblených klastů bylo velmi podobné ve všech studovaných vzorcích a pohybuje se mezi 20-30\%. Zaoblených valounů bylo průměrně $6 \%$. Dominují diskovité klasty (kolem $38 \%$ ) a klasty s čepelovitým tvarem (kolem $29 \%$ ). Klasty sloupcovité jsou méně hojné (kolem $20 \%$ ), stejně jako klasty sférického tvaru (kolem $13 \%$ ).

Pod elektronovým mikroskopem bylo zkoumáno 20 křemenných zrn. Většinou se jednalo o poloostrohranná zrna diskovitého či sférického tvaru. Nejčastější zjištěnou mikrotexturou byly obloukové stupně, V-jamky a křemičité povlaky.

\section{Interpretace}

Z geologické mapy 1: 50000 (list 24-23 Protivanov) je zřejmé, že neogenní sedimenty v okolí Ptení tvoří pruh, který se táhne ve směru SSZ-JJV, přičemž se směrem k SSZ postupně zužuje. Lze předpokládat, že se jedná o relikt paleoúdolí, kterým následně spodnobadenské moře proniklo směrem do Českého masivu (záliv?). Potenciálně podobné zálivy jsou často vázány na zahloubená údolí, jejichž původ je spojen s fluviální erozí. Sedimentární profil ukazuje dva nahoru zjemňující cykly spojené s protichůdnou činností přínosu klastického materiálu a rychlostí tvorby akomodačního prostoru (transgresivně-regresivní cykly).

Spodní nahoru hrubnoucí cyklus vykazuje mocnou FA 1 odrážející přepracování fluviálního/deltového materiálu pobliž břežní linie a převahu prrínosu klastického materiálu nad tvorbou depozičního prostoru („normální“ regrese). Nadložní FA 2 dokládá nárůst relativní hladiny spojený s vyšší rychlostí tvorby akomodačního prostoru, než byl př́nos klastického materiálu. Dochází k retrogradaci břežní linie. Plochu maximální záplavy během tohoto cyklu klademe do metráže kolem 7,50-7,75 m (vzorky s maximálním zastoupením jílovito-prachovité frakce, nejvyšší koncentrací Th, K, SGR, poměru Th/U a relativně nízkou koncentrací U). Svrchní partie FA 2 odráží opět normální regresi spojenou s progradací břežní čáry a relativním poklesem hladiny. Tím je ukončen spodní cyklus. Holcová (ústní sdělení) mikropaleontologicky posoudila dva vzorky z hloubek 9,95 a 7,8 m. Na základě hojné př́itomnosti Reticulofenstra sp. srovnává depoziční podmínky se situací ve svrchních částech vrtu Lomnice 1 (Holcová et al. 2015) nebo vrtů Židlochovice (Doláková et al. 2014). Jedná se o oligotrofní podmínky s výraznými oscilacemi salinity a snad i hypersalinitou.

Svrchní cyklus začíná erozní bází tělesa FA 1. Tato situace je interpretována jako odraz relativního poklesu hladiny, nucené progradace břežní linie, prínosu materiálu a částečné depozice ve fluviálně-deltovém prostředí. Nadložní FA 3 pak odráží relativně rychlé prohloubení depozičního prostoru a postup břežní linie směrem do kontinentu (retrogradace - relativní nárůst hladiny). Došlo $\mathrm{k}$ rychlé tvorbě akomodačního prostoru, který nebyl kompenzován př́nosem sedimentárního materiálu. Uvedená situace mohla být akcentována sedimentací v rámci relativně omezené zátoky či zahloubeného údolí. Uvedené dva cykly změny relativní hladiny tak nemusí odpovídat dvěma transgresivním fázím známým ze spodnobadenské výplně karpatské předhlubně, ale odráží spíše místní podmínky dané morfologií okraje pánve s pravděpodobnou prítomností vodního toku (případně jeho ústí). Jedná se tedy spíše o cykly vyššího řádu, než jsou cykly spojené s výše uvedenými dvěma spodnobadenskými transgresemi. Plochu maximální záplavy v rámci celého profilu klademe do metráže kolem 2,8 m (poblíž vzorku se zjištěnou minimální koncentrací $U$, nízkými koncentracemi Th a K a maximálním zastoupením jílovito-prachovité frakce). 
Zdrojem psefitického materiálu byly naprosto dominantně horniny blízkého okolí studované lokality, tj. horniny kulmské facie moravskoslezského paleozoika. Růst zastoupení křemene ukazuje na relativně vyšší zralost směrem k bázi, což nejspíše odráží rozdíly v intenzitě zvětrávání a přemístění materiálu do depoziční pánve. Lze případně uvažovat také o rozdílné délce transportu. Relativně nízké zaoblení zrn psefitické a psamitické frakce ukazuje na relativně krátký transport a rychlou depozici (téměř bez efektu opracování v břežní zóně). Shodné výsledky petrografické analýzy, tvarové analýzy a studia zaoblení v hodnocených vzorcích hodnoceného profilu ukazují na relativní stabilitu zdrojové oblasti, mechanismu transportu i klimatu během depozice. Podobně lze interpretovat i stabilitu populací křemenných zrn psamitické frakce zjištěnou exoskopicky.

\section{Poděkování}

Za laskavé posouzení príspěvku a pripomínky jsme povinováni díkem RNDr. Jiř́mu Otavovi, CSc. a Mgr. Michalu Francírkovi, Ph.D.

\section{Literatura}

Adams, J. A. S., Weaver, E. (1958). Thorium to uranium ratios as indicators of sedimentary process: example of concept of geochemical facies. - AAPG Bulletin, 42, 387-430.

Doláková, N., Holcová, K., Nehyba, S., Hladilová, Š., Brzobohatý, R., Zágoršek, K., Hrabovský, J., Seko, M., Utescher, T. (2014). The Badenian parastratotype at Židlochovice from the perspective of the multiproxy study. - Neues Jahrbuch für Geologie und Paläontologie Abhandlungen, 271, 169-201.

Doveton, J. H. (1991). Lithofacies and geochemical facies profiles from nuclear wireline logs: new subsurface templates for sedimentary modelling. - In: Franseen, E. K., Watney, W. L., Kendall, C. J., Ross, W. (eds): Sedimentary modelling-computer simulations and methods for improved parameter definition. - Kansas Geological Society Bulletin, 233, 101-110.

Folk, R. L., Ward, W. (1957). Brazos River bar: a study in the significance of grain-size parameters. - Journal of Sedimentary Petrology, 27, 3-26. Tulsa.

Hesselbo, S. P. (1996). Stratigraphy, Cenozoic of the Atlantic margin, offshore New Jersey. - In: Mountain, G. S., Miller, K. G., Blum, P., Poag, C. W., Twichell, D. C. (eds): Proceedings of the Ocean Drilling Program. - Scientific Results, 150, 411-422.

Holcová, K., Brzobohatý, R., Kopecká, J., Nehyba, S. (2015). Reconstruction of the unusual Middle Miocene (Badenian) palaeoenvironment of the Carpathian Foredeep (Lomnice/Tišnov denudational relict, Czech Republic). - Geological Quarterly, 59, 4, 654-678. https://doi.org/10.7306/gq.1249

Jedlitschka, J. (1937). Paleontologický výzkum slínů, jílů a písků z okolí Plumlova. - Věstník přírodovědeckého klubu za roky 1936-1937, 25, 11-41. Prostějov.

Kalabis, V. (1935). Příspěvek k seznání miocénu u Ptení a Ždetína. - Věstník klubu přírodovědeckého v Prostějově za roky 1934-1935, 24, 24-26. Prostějov.

Kalabis, V. (1939). Nový nález litavského vápence u Ptení. - Př́roda, 32, 10, 339-340. Brno.

Myers, K. J., Wignall, P. B. (1987). Understanding Jurassic organic-rich mudrocks - new concepts using gamma-ray spectrometry and palaeoecology: examples from the Kimmeridge Clay of Dorset and the Jet Rock of Yorkshire. - In: Legget, J. K., Zuffa, G. G. (eds): Marine clastic sedimentology: London, Graham and Trotman, 172-189.

Nehyba, S., Jašková, V. (2012). Výsledky vrtného průzkumu na lokalitě Hluchov (sedimenty spodního badenu karpatské předhlubně). - Geologické výzkumy na Moravě a ve Slezsku, 19, 1-2, 36-41. Brno.

Nemec, W. (2005). Principles of lithostratigraphic logging and facies analyses. - Institutt for geovitenskap, Uni. Bergen, 1-28.

Novák, Z. (1975). Spodnobadenské vápence karpatské předhlubně. - MS, Kandidátská disertační práce, Přírodovědecká fakulta Univerzity J. E. Purkyně. Brno.

Powers, M. C. (1982). Comparison chart for estimating roundness and sphericity. - AGI Data Sheet 18.

Remeš, M. (1933). Dodatky ke geologické mapě okolí olomouckého (speciální mapa č. 4158) a poznámky k některým listům sousedním (č. 4059, 4159, 4258, 4259), Část druhá. - Zprávy Komise na přírodovědecký výzkum Moravy a Slezska. Oddělení geologické, č. 12, Brno.

Spitzner, V. (1898). Geologická reliéfní mapa okresu prostějovského a plumlovského, v měřítku $1: 25000$ - První výroční zpráva Klubu prŕrodovědeckého v Prostějově za rok 1898, 42-45, Prostějov.

Spitzner, V. (1904). Foraminifery (dírkonosci) v třetihorních jílech v okolí Prostějova u Ptení a Čech. - Věstník Klubu přírodovědeckého za rok 1903, 6, 142-145. Prostějov.

Synek, M. (1998). Výzkum miocénu u Ptení. - Přírodovědné studie Muzea Prostějovska. Svazek 1, Sborník k 100. výročí založení klubu Přírodovědeckého v Prostějově. 140. Prostějov.

Tomanová Petrová, P. (2016). Sedimenty karpatu a spodního badenu na lokalitě Brus. - Zprávy o geologických výzkumech, 49, 171-176. Praha.

Tucker, M. ed. (1988). Techniques in Sedimentology. - Blackwell Science, 1, 394.

Walker, R. G., James, N. P. (1992). Facies Models. Response to sea level changes. - Geological Association of Canada, 1-380, Toronto. 
Zágoršek, K., Nehyba, S., Tomanová Petrová, P., Hladilová, Š., Bitner, M. A., Doláková, N., Hrabovský, J., Jašková, V. (2012). Local catastrophe near Přemyslovice (Moravia, Czech Republic) during Middle Miocene due to the tephra input. - Geological Quarterly, 56, 2, 269-284. http://dx.doi.org/10.7306/gq.1021

Zborník, V., Nehyba, S., Jašková, V. (2013). Výsledky vrtného průzkumu na lokalitě Brus (neogenní sedimenty karpatské předhlubně). - Geologické výzkumy na Moravě a ve Slezsku, 20, 1-2, 63-68. Brno. 